\title{
BANTUAN HUKUM MELALUI MEKANISME NONLITIGASI SEBAGAI SALURAN PENGUATAN PERADILAN INFORMAL BAGI MASYARAKAT ADAT
}

\author{
(The Legal Aid Through Non Litigation Mechanism As Access \\ on Strengthening Informal Justice for Adat Community)
}

\author{
Arfan Faiz Muhlizi \\ Pusat Penelitian dan Pengembangan Sistem Hukum Nasional \\ Badan Pembinaan Hukum Nasional \\ Jl. Mayjen Sutoyo No.10 Cililitan Jakarta \\ Email: arfan_fm@yahoo.com, arfan.fm@gmail.com
}

Naskah diterima: 22 April 2013; revisi: 24 April 2013; disetujui: 26 April 2013

\begin{abstract}
Abstrak
Kemampuan negara dalam menyediakan akses atas keadilan secara cepat dan murah bagi masyarakat masih menghadapi berbagai kendala, mulai dari terbatasnya jangkauan aparat negara, hingga terjadinya judicial corruption. Oleh karena itu perlu mencari alternatif lain dalam rangka mendapatkan akses keadilan. Salah satu alternatif tersebut adalah penguatan mekanisme non formal melalui peradilan informal dengan berbagai variannya seperti mediasi dan peradilan adat. Penyelesaian sengketa melalui mekanisme non formal ini selaras dengan keberadaan Undang-Undang (UU) No. 16 Tahun 2011 tentang Bantuan Hukum, yang memberikan ruang bagi kemungkinan bantuan hukum melalui mekanisme nonlitigasi. Dengan menggunakan pendekatan yuridis empiris dan mengacu pada model collaborative approach atau hybrid justice sistem agar dapat memberikan jaminan kepastian hukum maka terlihat bahwa UU Bantuan Hukum juga mendorong pembenahan dan pembaharuan administrasi dan manajemen peradilan adat agar mekanisme koordinasi dengan lembaga formal dalam rangka memberikan bantuan hukum ini dapat berjalan lebih lancar. Pemerintah masih perlu mendorong agar organisasi bantuan hukum $(\mathrm{OBH})$ memberikan prioritas bantuan hukum terhadap kasus-kasus yang diselesaikan melalui peradilan informal, khususnya peradilan adat agar tidak terjadi penumpukan perkara di peradilan formal.
\end{abstract}

Kata kunci: peradilan adat, bantuan hukum, koordinasi, nonlitigasi

\section{Abstract}

State capabilities in providing access to justice rapidly and cheaply to peoples still faces various obstacles, begin from limited reach of civil servant until judicial corruption happened. Therefore it is necessary to find other alternatives in order to obtain access of justice. The one of it is strengthening mechanism through informal justice with variety of variant such as mediation and adat court. Dispute resolution through non formal mechanism in line with existence the law number 16 year 2011 on legal aid which provides space for the possibility of legal aid through non litigation mechanism. By using empirical and juridical approach refers to the collaborative approach or a hybrid justice system in order to provide legal certainty then it looks that the law on legal assistance encouraging improvement and renewal of adat court in order to provide legal aid runs smoothly. The government still necessary to encourage legal aid institution gives priority to legal aid of cases resolved by informal justice, especially of adat justice in order to avoid the buildup of cases in formal justice.

Keywords: adat judiciary, legal aid, coordination, nonlitigation 


\section{A. Pendahuluan}

Sebagai sebuah negara hukum (Rechtstate) konstitusi Indonesia menjamin persamaan setiap warga negara di hadapan hukum (equality before the (aw), sebagai salah satu prinsip dasar yang menjadi tuntunan dalam kehidupan berbangsa dan bernegara. Karena itu, setiap warga negara berhak memperoleh pemulihan (remedy) atas pelanggaran hak yang mereka derita dan negara memiliki kewajiban untuk memastikan pemenuhan hak-hak tersebut. Dengan demikian, akses atas keadilan adalah suatu hak asasi manusia yang wajib dihormati dan dijamin pemenuhannya.

Namun harus diakui bahwa pencapain ke arah cita ideal tersebut memerlukan dukungan dan kerja nyata oleh semua pihak. Hal ini dikarenakan Indonesia baru saja terlepas dari masa dimana prinsip sebagai negara hukum diingkari dengan berbagai praktek penyelewengan kekuasaan (abuse of power) di masa orde baru. Akses terhadap keadilan dalam konteks Indonesia mengacu pada keadaan dan proses di mana negara menjamin terpenuhinya hak-hak dasar berdasarkan UUD 1945 dan prinsip-prinsip universal hak asasi manusia, dan menjamin akses bagi setiap warga negara (claim holder) agar dapat memiliki kemampuan untuk mengetahui, memahami, menyadari dan menggunakan hak-hak dasar tersebut melalui lembaga-lembaga formal maupun informal, didukung oleh keberadaan mekanisme keluhan publik (public complaint mechanism) yang mudah diakses masyarakat dan responsif, agar dapat memperoleh manfaat yang optimal untuk memperbaiki kualitas kehidupannya sendiri.
Kenyataan akan keterbatasan kemampuan institusi negara (Kepolisian dan Pengadilan) dalam menyediakan akses atas keadilan secara cepat bagi masyarakat, juga masih menghadapi berbagai kendala. Jauhnya akses ke peradilan formal, biaya yang tinggi dan kurangnya pemahaman tentang peradilan formal serta terbatasnya jangkaun layanan Kepolisian, seringkali menjadi hambatan bagi masyarakat miskin dan marginal untuk menyelesaikan persoalan yang mereka hadapi melalui institusi formal.

Terdapat beberapa hasil penelitian yang menunjukkan terjadinya judicial corruption telah menggurita pada setiap tahap proses peradilan. ${ }^{1}$ Penelitian yang dilakukan oleh Bappenas dan World Bank (Cyberconsult tahun 1999) menunjukkan adanya praktik korupsi di lingkungan peradilan. Secara khusus, laporan ini menyoroti praktek korupsi yang dilakukan oleh panitera pada saat pendaftaran perkara. Responden penelitian tersebut menyatakan bahwa biaya pendaftaran yang harus dibayar oleh pencari keadilan menjadi cukup mahal melebihi dari apa yang seharusnya dibayar menurut ketentuan yang berlaku. Bertolak dari penelitian tersebut juga diungkap pula praktik korupsi bagi para pihak ketika mendapatkan salinan putusan. Salinan putusan yang semestinya menjadi hak dari para pihak, namun ternyata hanya bisa didapatkan oleh para pihak setelah diharuskan untuk memberikan sejumlah uang lebih kepada petugas di pengadilan. Tanpa uang lebih, maka salinan putusan tidak akan segera diserahkan. ${ }^{2}$

Penelitian lain yang dilakukan oleh Mardjono Reksodiputro juga mengungkapkan adanya

Basuki Rekso Wibowo, Pembenahan Administrasi Peradilan (Jakarta: BPHN, 2012), hlm. 7-10.

Wasingatu Zakiya dkk, Panduan Eksaminasi Publik (Jakarta: Indonesia Corruption Watch (ICW), 2003), hlm. 4. Lihat juga Basuki Rekso Wibowo, Pembenahan Administrasi Peradilan (Jakarta: BPHN, 2013), hlm. 7-10. 
praktik mafia peradilan. Bahkan dari penelitian tersebut dipetakan mengenai modus-modus korupsi yang dilakukan oleh kepolisian, kejaksaan dan hakim di Pengadilan. Di kepolisian, Mardjono mengutip istilah yang berkembang di masyarakat "lapor ayam hilang, kambingpun turut hilang". Maksudnya apabila korban kejahatan melapor ke polisi akan mengeluarkan lebih banyak uang untuk ikut "menanggung" biaya operasional dari polisi. Selain itu, pemberian fasilitas lebih kepada tahanan, terutama yang kaya, disertai sejumlah imbalan tertentu, juga telah lama menjadi bahan pergunjingan di masyarakat. Sedangkan di kejaksaan, Mardjono Reskodiputro mengungkapkan bahwa, selain melakukan pemerasan terhadap tersangka, jaksa juga bisa melepaskan tersangka dengan alasan kurang bukti. Mempermainkan pasal dakwaan, mempermainkan tinggi rendahnya tuntutan pidana merupakan modus yang cukup sering djiumpai dalam praktek. Mempermainkan perlu tidaknya menggunakan kewenangan untuk melakukan penahanan terhadap tersangka atau terdakwa juga merupakan penyalahgunaan wewenang, baik ketika tahap penyidikan di kepolisian maupun penuntutan di kejaksaan. Alasan tersebut yang seharusnya didukung oleh fakta obyektif namun telah bergeser menjadi pertimbangan subyektif belaka. Selain itu, praktik di pengadilan juga turut diungkap oleh Mardjono. ${ }^{3}$ Terutama yang menyangkut putusan yang akan dijatuhkan, apabila dalam perkara perdata apakah suatu gugatan akan dikabulkan, gugatan ditolak, atau gugatan dinyatakan tidak dapat diterima; dalam perkara pidana apakah terdakwa akan dinyatakan terbukti bersalah dan dikenakan pemidanaan, serta menentukan tinggi rendahnya pidana yang dijatuhkan; menyatakan dakwaan jaksa penuntut umum tidak terbukti dengan membebaskan terdakwa dari segala dakwaan (vrijspraak); atau menyatakan melepaskan terdakwa dari segala tuntutan (ontslag van alle rechtsvervolging), serta berbagai modus yang lainnya. Hal tersebut sangat dipengaruhi oleh demikian longgar dan elastisnya penggunaan diskresi oleh hakim, dengan berlindung di balik asas bahwa hakim memiliki kebebasan untuk memutus suatu perkara yang diajukan kepadanya, berdasarkan keyakinan yang dimilikinya serta penilaiannya terhadap fakta persidangan. Penggunaan dan penerapan kewenangan yang dimilikinya tersebut, sangat terbuka adanya kemungkinan untuk disalahgunakan sedemikian rupka sehingga menimbulkan terjadinya judicial corruption. Semuanya itu sudah barang tentu akan sangat bergantung pada seberapa kuatnya etika, integritas dan komitmen aparat penegak hukum itu sendiri.

Selain dua penelitian di atas, terdapat satu makalah yang menyangkut bagaimana praktik judicial corruption selalu mengikuti dalam setiap tahapan proses beracara. Berdasarkan pengalamannya sebagai pengacara, Kamal Firdaus memetakan praktik korupsi di pengadilan tingkat pertama dan pengadilan tingkat banding dalam persidangan perdata. ${ }^{4}$ Dalam pendaftaran perkara, Kamal mencatat bahwa para pihak, konon, bisa memilih siapa anggota majelis hakim yang akan mengadili

Basyaib et.al., Korupsi Dalam Sistem Hukum (Jakarta: Partnership for Governance Reforfm in Indonesia, 2002). Lihat juga Wasingatu Zakiya dkk, Panduan Eksaminasi Publik (Jakarta: Indonesia Corruption Watch (ICW), 2003), hlm.4-5, serta Basuki Rekso Wibowo, Pembenahan Administrasi Peradilan (Jakarta: BPHN, 2013), hlm. 7-10.

4 Basuki Rekso Wibowo, Pembenahan Administrasi Peradilan (Jakarta: BPHN, 2013), hlm. 7-10. 
perkaranya, tentunya dengan berkolusi dengan Ketua atau Wakil Ketua Pengadilan, untuk mengatur komposisi majelis hakim serta panitera penggantinya.

Berikutnya, dalam proses persidangan, konon, kemenangan dalam vonis juga bisa diatur. Atau sebaliknya, diatur bagaimana agar hakim menolak gugatan pihak lawan. Kemudian dalam eksekusi, Kamal juga melihat adanya surat sakti atau telepon sakti kepada Ketua Pengadilan tingkat pertama agar eksekusi terhadap sesuatu putusan segera dilakukan, ditangguhkan atau bahkan dibatalkan. Lalu dalam tahap beracara di Pengadilan Tinggi (PT), apakah suatu putusan banding akan menguatkan atau membatalkan vonis hakim di pengadilan tingkat pertama bisa diatur. Dipetakan pula siapa saja pelaku yang terlibat dalam setiap praktik korupsi dalam tahap beracara di peradilan perdata. ${ }^{5}$

Dengan demikian, dewasa ini cara penyelesaian sengketa melalui peradilan mendapat kritik yang cukup tajam, baik dari praktisi maupun teoritisi hukum. Selain terjadinya judicial corruption, peran dan fungsi peradilan, dianggap mengalami beban yang terlampau padat (overloaded), lamban dan buang waktu (waste of time), biaya mahal (very expensif) dan kurang tanggap (unresponsive) terhadap kepentingan umum, atau dianggap terlalu formalistis (formalistic) dan terlampau teknis (technically).

Dari berbagai data yang diuraikan di atas, menjadi sangat beralasan ketika lahir berbagai pemikiran untuk mencari alternative lain dalam rangka mendapatkan akses keadilan di luar pengadilan formal. ${ }^{6}$ Salah satu gagasan tersebut adalah penguatan peradilan informal (informal justice) dengan berbagai variannya seperti mediasi dan peradilan adat. Salah satu perundang-undangan yang mendukung keberadaan peradilan adat adalah UU No.16 Tahun 2011 tentang Bantuan Hukum (selanjutnya disebut juga UU Bantuan Hukum) yang memungkinkan diberikannya bantuan hukum nonlitigasi.?

\section{B. Permasalahan}

Dari uraian di atas, masih terdapat beberapa permasalahan teoritik maupun sosiologis yang perlu mendapatkan kejelasan sebagaimana dapat dirumuskan sebagai berikut:

1. Apakah bantuan hukum yang diberikan kepada penerima bantuan hukum yang menyelesaikan perkaranya melalui peradilan adat dapat masuk dalam kategori bantuan hukum nonlitigasi yang diatur dalam UU No.16 Tahun 2011 tentang Bantuan Hukum?

2. Jika bantuan hukum yang diberikan kepada penerima bantuan hukum yang menyelesaikan perkaranya melalui peradilan adat dapat masuk dalam kategori bantuan hukum nonlitigasi yang diatur dalam UU No.16 Tahun 2011 tentang Bantuan Hukum, apakah hal ini memberikan pengaruh positif bagi penguatan peradilan adat dalam komunitas adat yang masih hidup?

Ibid.

6. Pengadilan formal yang dimaksud dalam tulisan ini adalah yang diatur dalam UU No. 48 Tahun 2009 tentang Kekuasaan Kehakiman.

7 Pasal 4 UU No. 16 Tahun 2011 tentang Bantuan Hukum menyatakan bahwa Bantuan Hukum meliputi masalah hukum keperdataan, pidana, dan tata usaha negara baik litigasi maupun nonlitigasi. 


\section{Metode Penelitian}

Berdasarkan permasalahan dan latar belakang di atas, penelitian ini dilakukan dengan menggunakan pendekatan yuridis empiris ${ }^{8}$, yaitu pendekatan yang digunakan untuk melihat gejala-gejala sosial yang berkaitan dengan hukum di tengah masyarakat. Pendekatan yuridis empiris mengkaji bagaimana ketentuan normatif diwujudkan senyatanya di masyarakat. Penelitian ini juga menggunakan pendekatan yuridis normatif ${ }^{9}$ karena menggunakan data sekunder sebagai sumber tambahan, berupa berbagai peraturan perundang-undangan dan referensi dokumen lain yang terkait dengan bantuan hukum dan peradilan adat. Sedangkan dilihat dari sifatnya, penelitian ini termasuk penelitian yang bersifat deskriptif analitis yakni akan menggambarkan secara keseluruhan obyek yang diteliti secara sistematis dengan menganalisis data yang diperoleh.

\section{Pembahasan}

\section{Peradilan Adat Sebagai Mekanisme NonLitigasi}

Untuk mengetahui apakah bantuan hukum non litigasi dapat diberikan kepada masyarakat yang menyelesaikan perkaranya melalui peradilan adat maka perlu dipahami terlebih dulu bagaimana konsep bantuan hukum dalam UU Bantuan Hukum. Dalam Pasal 1 UU Bantuan Hukum disebutkan bahwa Bantuan Hukum adalah jasa hukum yang diberikan oleh Pemberi ${ }^{10}$ Bantuan Hukum secara cuma-cuma kepada Penerima ${ }^{11}$ Bantuan Hukum. Selanjutnya di dalam Pasal 4 UU Bantuan Hukum disebutkan bahwa bantuan Hukum meliputi masalah hukum keperdataan, pidana, dan tata usaha negara baik litigasi maupun nonlitigasi.

Penyelesaian perkara nonlitigasi adalah suatu pranata penyelesaian sengketa di luar pengadilan atau dengan cara mengesampingkan penyelesaian secara litigasi di Pengadilan Negeri. Dalam pasal (1) angka (10) UU No. 30 Tahun 1999 tentang Arbitrase dan Alternatif Penyelesaian Sengketa, disebutkan bahwa masyarakat dimungkinkan memakai alternatif lain dalam melakukan penyelesaian sengketa. Alternatif tersebut dapat dilakukan dengan cara konsultasi, negosiasi, mediasi, konsiliasi, atau penilaian ahli dan juga dengan penafsiran terbuka bisa ditambahkan pula mekanisme peradilan adat.

Ada beberapa alasan perlunya didorong proses penyelesaian sengketa nonligitasi melalui peradilan adat dalam penyelesaian sengketa. Pertama, di Indonesia tata cara penyelesaian sengketa damai telah lama dan biasa dipakai

$8 \quad$ Penelitian empiris adalah penelitian yang dilakukan dengan cara meneliti data-data primer, yaitu data yang diperoleh langsung dari masyarakat. Pemikiran empiris ini disebut juga pemikiran sosiologis. Lebih jauh tentang ini lihat Soerjono Soekanto dan Sri Mamudji, Penelitian Hukum Normatif: Suatu Tinjauan Singkat (Jakarta: CV. Rajawali, 1990), hlm. 15.

9 Penelitian normatif adalah penelitian yang dilakukan dengan cara meneliti bahan pustaka atau data sekunder belaka. Pemikiran normatif didasarkan pada penelitian yang mencakup (1)asas-asas hukum, (2) sistematik hukum, (3) taraf sinkronisasi vertikal dan horisontal, (4)perbandingan hukum, (5)sejarah hukum. Lebih jauh tentang ini lihat Soerjono Soekanto dan Sri Mamudji, Penelitian Hukum Normatif: Suatu Tinjauan Singkat, edisi 1, cet. v, (Jakarta: PT Raja Grafindo Persada, 2001), hlm. 13-14. Lihat juga Soerjono Soekanto dan Sri Mamudji, Peranan dan Penggunaan Perpustakaan di Dalam Penelitian Hukum (Jakarta: Pusat Dokumentasi Hukum Fakultas Hukum Universitas Indonesia, 1979). hlm. 15.

10 Pemberi Bantuan Hukum adalah lembaga bantuan hukum atau organisasi kemasyarakatan yang memberi layanan Bantuan Hukum berdasarkan Undang-Undang ini.

11 Penerima Bantuan Hukum adalah orang atau kelompok orang miskin. 
oleh masyarakat Indonesia. ${ }^{12} \mathrm{Hal}$ ini dapat dilihat dari hukum adat yang menempatkan kepala adat sebagai penengah dan memberi putusan adat bagi sengketa di antara warga. ${ }^{13}$ Berbagai suku bangsa di Indonesia mempunyai budaya penyelesaian sengketa secara damai, misalnya masyarakat Jawa ${ }^{14}$, Bali, $^{15}$ Sulawesi
Selatan, ${ }^{16}$ Sulawesi Tengah, ${ }^{17}$ Sumatera Barat, Dayak ${ }^{18}$, Sumatera Selatan, Lampung, Lombok, Irian Jaya ${ }^{19}$ dan masyarakat Toraja. ${ }^{20}$

Menurut Sinclair Dinnen mekanisme ini masih berlaku didaerah-daerah pedalaman dibanyak negara didunia. Hal ini terjadi karena beberapa hal antara lain: ${ }^{21}$

12 Ahmadi Hasan, Penyelesaian Sengketa Hukum Berdasarkan Adat Badamai Pada Masyarakat Banjar dalam Kerangka Sistem Hukum Nasional, Disertasi pada Program Doktor Ilmu Hukum Pasasarjana Fakultas Hukum Universitas Islam Indonesia, Yogyakarta, Tahun 2007. Lihat juga Muhammad Koesno, Musyawarah dalam Miriam Budiardjo (Ed.), Masalah Kenegaraan, (Jakarta: tanpa penerbit, 1971), hlm. 551.

13 Misalnya di Minangkabau yang bertindak sebagai mediator yang juga mempunyai wewenang untuk memberikan putusan atas perkara yang dibawa kehadapannya adalah sebagai berikut: 1). Tungganai atau mamak kepala waris ada tingkatan rumah gadang, 2). Mamak kepala kaum pada tingkat kaum, 3). Penghulu suku pada tingkat suku, dan 4). Penghulu-penghulu fungsional pada tingkatan nagari. Fungsionmarisntersebut berperan penting dalam menyelesaikan sengketasengketa, baik sebagai penengah dengan (sepadan dengan arbiter atau hakim) atau tanpa kewenangan mamutus (sebagai mediator), Takdir Rahmadi dan Achmad Romsan, Teknik Mediasi Tradisional Dalam Masyarakat Adat Minangkabau, Sumatera Barat dan Masayarakat Adat di Dataran Tinggi, Sumatera Selatan, (Jakarta: Indonesia Center For Environmental Law (ICEL), The Ford Foundation 1997-1998).

14 Dalam wawancara penulis tanggal 20 Juli 2011 dengan Kepala Desa Ngadisari di Lereng Gunung Bromo Jawa Timur yang bernama Supoyo menyebutkan bahwa lembaga adat berperan sebagai sistem kemasyarakatan yang mengatur struktur hirarki sosial dan kelompok masyarakat, serta menjaganya pada suatu harmoni. Dalam wawancara tersebut disebutkan juga bahwa orang Tengger memiliki petunjuk yang mengarah kepada keharmonisan dan kelestarian dalam persaudaraan, seperti yang terdapat dalam "sesanti pancasetia” (lima petunjuk kesetiaan). Sesanti itu adalah: "setya budaya” (taat dan hormat kepada adat), "setya wacana” (kata harus sesuai dengan perbuatan), ”setya semaya” (selalu menepati janji), ”setya laksana” (bertanggung jawab terhadap tugas) dan "setya mitra” (selalu membangun kesetiakawanan). Orang Tengger juga memiliki empat falsafah ketaatan: taat kepada Tuhan, taat kepada orang tua (termasuk para leluhur), taat kepada guru (orang yang memberikan pengetahuan atau ilmu kepada mereka), serta taat kepada pemerintah. Lebih jauh lihat juga Laporan Pemantauan dan Inventarisasi Perkembangan Hukum Adat yang dilaksanakan tim BPHN tahun 2011.

15 Daniel S. Lev, Hukum dan Politik di Indonesia (Jakarta: LP3ES, 1990), hlm. 158.

16 H.M.G. Ohorela dan H. Aminuddin Salle, Penyelesaian Sengketa Melalui Arbitrase pada Masyarakat di Pedesaan di Sulawesi Selatan, dalam Felix O. Soebagjo dan Erman Rajagukguk (ed.), Arbitrase di Indonesia (Jakarta: Ghalia Indonesia, 1995), hlm. 105-119.

17 Dalam dialog dengan Andreas Lagimpu, tokoh adat Sigi dan beberapa workshop di Palu bersama para tokoh adat Sulawesi Tengah sebagai rangkaian kegiatan Strengthening Access to justice in Indonesia (SAJI) Project, pada 12-13 November 2012, 19-20 Desember 2012 dan 12-13 April 2013, terlihat bahwa Masyarakat Sulawesi mempunyai lembaga adat yang beragam karena terdapat banyak suku. Meski demikian lembaga adat mempunyai peran besar dalam mendamaikan dan bahkan menyembuhkan perselisihan antar warga.

18 Dalam wawancara dengan beberapa tokoh adat Dayak seperti Sabran Ahmad, Ketua Dewan Adat Dayak Provinsi Kalimantan Tengah, Dr. Siun Janias, Sekretaris Dewan Adat Dayak Provinsi Kalimantan Tengah, sekaligus Sekretaris Daerah rovinsi Kalimantan Tengah, Basal A Bangkana Damang Wilayah Kadamangan Sabangau Palangkaraya dan Prof. H.KMA. M.Usop, M.A, Ketua Lembaga Musyawarah Masyarakat Dayak dan Daerah Kalimantan Tengah (LMMDD-KT) sebagai rangkaian kegiatan Strengthening Access to justice in Indonesia (SAJI) Project di 2012 dan 2013, terlihat bahwa lembaga adat mempunyai peran besar dalam mendamaikan dan bahkan menyembuhkan perselisihan antar warga. Mereka menyebut bahwa tujuan utama peradilan adat adalah perdamaian. Hilman Hadikusuma, Pengantar Antropology Hukum, (Bandung: Citra Aditya Bakti, 1992), hlm. 177-205.

T.0. Ihromi (ed.), Antropology dan Hukum (Jakarta: Yayasan Obor Indonesia, 1984), hlm. 17.

Sinclair Dinnen, "Interfaces Between Formal and Informal Justice Sistem To Strengthen Access to Justice By Disadvantaged Sistem" (Makalah disampaikan dalam Practice In Action Workshop UNDP Asia-Pasific Rights and Justice Initiative, Ahungala Sri Lanka, 19-21 November 2003 sebagaimana dikutip Eva Achjani Zulfa, "Keadilan Restoratif dan Revitalisasi Lembaga Adat Di Indonesia," Jurnal Kriminologi Indonesia Vol. 6 No. II Agustus (2010): 182-203. 
(a) Terbatasnya akses masyarakat terhadap sistem hukum formal yang ada;

(b) Masyarakat tradisional didaerah terisolasi pada dasarnya masih memiliki tradisi hukum yang kuat berdasarkan hukum tradisionalnya dalam memecahkan permasalahan hukum yang terjadi. Hal ini merupakan realitas dimana tradisi atau "custom" masih berlaku di banyak tempat. Ini juga merupakan realita dimana perubahan masyarakat kadang kala terbentur batas wilayah, dan bahwa hal ini juga merupakan kenyataan dimana terdapat daerah-daerah yang masih "steril" keberlakukan sistem hukum formal).

(c) Tipe pemecahan masalah yang ditawarkan sistem hukum formal terkadang memperoleh pandangan yang berbeda dan dianggap kurang memadai dan kurang memenuhi rasa keadilan masyarakat yang masih memegang tradisi hukum mereka sendiri;

(d) Kurang memadainya infrastruktur dan sumber daya yang dimiliki oleh sistem hukum formal menyebabkan kurangnya daya adaptasi dalam menyerap kebutuhan rasa keadilan masyarakat setempat.

Kedua, pada sebagian besar masyarakat Indonesia terdapat kecenderungan menye- lesaikan sengketa dengan cara damai. Cara ini diakui efektif dalam menyelesaikan pertikaian atau persengketaan. Sekaligus mampu menghilangkan perasaan dendam ${ }^{22}$, serta berperan menciptakan keamanan ketertiban dan perdamaian. Berdasarkan penelitian beberapa pakar, pada dasarnya budaya untuk konsiliasi atau musyawarah ${ }^{23}$ merupakan nilai masyarakat yang meluas di Indonesia. Kenyataan ini juga diperkuat laporan survey The Asia Foundation mengenai persepsi masyarakat Indonesia terhadap sektorhukum dan keadilan di Indonesia dimana eksistensi pengadilan adat masih sangat kuat. Laporan tersebut menyatakan bahwa: ${ }^{24}$ 86 percent of respondents believe that musyawarah is preferable to court or other formal procedures as a means of settling legal disputes. At the same time, 49 percent feel that the absence of a legally binding outcome under musyawarah is a problem. 62 percent would avoid going to court at all costs.

Ketiga, keberadaan peradilan adat menjadi semakin penting ditengah situasi negara yang belum sepenuhnya mampu menyediakan layanan penyelesaian perkara melalui jalur formal sampai ke desa-desa terpencil. Selain itu, kapasitas peradilan formal yang juga berat karena terjadi penumpukan perkara yang yang

22 Ahmadi Hasan, "Penyelesaian Sengketa Melalui Upaya (Non Ligitasi) Menurut Peraturan Perundang-Undangan," Jurnal Al-Banjari Vol. 5, No. 9, Januari-Juni (2007).

23 Dalam bahasa Arab, perkataan musyawarah berasal dari kata dasar syawarayasyuru-musyawarah atau syura yang artinya tanda, petunjuk, nasehat, pertimbangan. Dengan demikian, berdasarkan asal-muasalnya, kata musyawarah merupakan kata kerja yang dibendakan dan mengandung makna"saling memberi isyarat, petunjuk, atau pertimbangan yang bermakna resiprokal dan mutual". Kata "musyawarah" dalam terminologi ketatanegaraan Indonesia biasanya disandingkan dengan kata "mufakat" yang berasal dari bahasa Arab. Istilah ini bersal dari asal kata itifaq-muwafawah yang berarti "memberikan persetujuan atau kesepakatan". Persetujuan di sini dapat berupa suara yang terbanyak dan secara teknis dilakukan lewat pemungutan suara atau consensus bulat. Akan tetapi, dalam pengertian teknis di Indonesia dewasa ini, istilah "musyawarah mufakat" mengandung pengertian "consensus bulat." Lihat Nurchalish Madjid, Islam Agama Kemanusiaan: Membangun Tradisi dan Visi Baru Islam Indonesia (Jakarta: Paramadina, 1995), hlm. 194. dan M. Quraish Shihab, Wawasan Al-Qur'an, (Bandung: Mizan, 1996), hlm. 361. Dan lihat Adi Sulistyono, Mengembangkan Paradigma Non-Ligitasi di Indonesia, (Surakarta: Sebelas Maret University Press, 2006), hlm. 31.

24 The Asia Foundation, Survey Report on Citizens' Perceptions of The Indonesian Justice Sector (Preliminary Findings and Recommendations). The Asia Foundation, 2001. 
sangat serius. Sebagai catatan, bila dilihat pada institusi tertinggi peradilan negara, data Yayasan Lembaga Hukum Indonesia(YLBHI)menunjukkan bahwa "setiap tahun ada 13 ribu perkara yang masuk ke Mahkamah Agung. Jumlah sebanyak itu harus diselesaikan oleh 54 Hakim Agung yang selalu menyisakan 8 ribu kasus tiap akhir tahun". ${ }^{25}$ Banyaknya jumlah perkara itu telah memberikan beban nyata bagi institusi peradilan formal dalam menghadirkan akses terhadap keadilan bagi masyarakat. Belum lagi biaya yang relatif besar dikeluarkan oleh masyarakat untuk menjalani proses peradilan formal karena membutuhkan biaya untuk transportasi ke lokasi pengadilan serta membayar jasa penasehat hukum yang mendampingi pihak berperkara. Beban yang sedemikian berat ini tentu akan dapat dikurangi dengan memberikan porsi yang lebih besar kepada peradilan adat agar dapat mengambil peran dalam upaya membuka akses keadilan yang lebih lebar bagi masyarakat.

Dengan disahkannya UU Bantuan Hukum, yang memberikan ruang bantuan hukum bagi penyelesaian perkara melalui jalur non litigasi diharapkan beban peradilan formal akan berkurang, sekaligus membuka akses lebih besar pada masyarakat untuk mendapatkan keadilan. Konsep yang dibangun oleh UU Bantuan Hukum menurujuk pada kenyataan bahwa di luar peradilan negara juga terdapat peradilan non formal yang terpasang dan bekerja berdasarkan aturan-aturan tingkah laku dalam menyelesaikan sengketa berdasarkan hukum adat yang hidup dalam masyarakat. Di sini peradilan dipandang sebagai komponen sistem kemasyarakat yang kompleks dan tidak sebagai sumber tunggal dalam distribusi keadilan, seperti dalam pemikiran hukum legalistispositivistik. Dengan demikian permasalahan distribusi keadilan tidak hanya dikaitkan dengan upaya pemerataan kesempatan memperoleh keadilan melalui pembentukan peradilan formal dan perangkat-perangkatnya ${ }^{26}$, tetapi juga dengan pasangan yang tepat antara forum dan sengketa, dan dengan postulat-postulat penataan sosial berdasarkan hukum adat. ${ }^{27}$ Alur pikir demikian membawa pada kesimpulan bahwa bantuan hukum yang diberikan kepada penerima bantuan hukum yang menyelesaikan perkaranya melalui peradilan adat dapat masuk dalam kategori bantuan hukum nonlitigasi yang diatur dalam pasal 4 UU No.16 Tahun 2011 tentang Bantuan Hukum.

Proses penyelesaian sengketa nonligitasi yang dibuka dalam UU Bantuan Hukum secara pragmatis juga dapat lebih mencegah politisasi perkara oleh pengacara yang pragmatis dengan tujuan sekedar mendapatkan dana bantuan hukum dari Negara dan membawanya ke ranah peradilan formal. Hal ini tentu akan berbeda pengaruhnya jika bantuan hukum itu hanya diberikan dalam proses litigasi. Terdapat

25 http:// news.detik.com/ read/2012/02/06/190613/1835694/10/tunggakan- 8-ribu-perkara- tiap-tahunjadi- tantangan-ketua-ma-baru?nd992203605 (diakses tanggal 1 Maret 2013). Lihat juga SAJI Project, Pedoman Peradilan Adat Di Sulawesi Tengah, 2013.

26 Ahmad Ubbe, "Perbandingan Antara Jumlah Hakim dengan Perkara, Penduduk dalam Pemerataan Memperoleh Keadilan," Majalah Hukum Nasional. No 2 (1989): 117.

27 Marc Galanter, "Keadilan Di Berbagai Ruang: Lembaga Peradilan, Penataan Masyarakat Serta Hukum Rakyat", Dalam T. O. Ihromi, Antropologi Hukum, Sebuah Bunga Rampai, (Jakarta: Yayasan Obor Indonesia, 1993), hlm. 95. Sebagaimana dikutip Ahmad Ubbe, "Peradilan Adat dan Keadilan Restoratif" (makalah disampaikan pada Workshop Penyempurnaan dan Strategi Impelementasi Pedoman Peradilan Adat Sulawesi Tengah, Palu, 12-13 April 2013). 
kekhawatiran bahwa jika hanya kasus litigasi yang mendapatkan dana bantuan hukum dari Negara maka justru para pengacara atau paralegal akan beramai-ramai membawa kasuskasus "kecil" atau kasus adat yang seharusnya bisa diselesaikan secara kekeluargaan atau adat justru dibawa ke peradilan formal demi mendapatkan dana bantuan hukum. Di samping itu, dengan beragam syarat administratif yang diatur oleh UU Bantuan hukum bagi pemberi dan penerima bantuan hukum akan berpengaruh kepada peradilan adat untuk membenahi pengelolaan administrasi dan manajemen peradilan adat yang selama ini masih kurang tertata. Dengan demikian secara tidak langsung bantuan hukum melalui proses non litigasi membantu menguatkan peradilan adat di Indonesia.

\section{Pengaruh Positif Bantuan Hukum Non Litigasi Bagi Penguatan Peradilan Adat}

Dalam Pasal 2 UU Bantuan Hukum dikatakan bahwabantuanhukum dilaksanakanberdasarkan asas; keadilan, persamaan kedudukan di dalam hukum, keterbukaan, efisiensi, efektivitas, dan akuntabilitas. Asas ini akan mendorong peradilan adat untuk melakukan beberapa pembenahan sebagai berikut: Pertama, harmonisasi nilai adat agar selaras dengan asas keadilan termasuk harmonisasi nilai adat agar tidak bertentangan dengan nilai keadilan universal seperti hak asasi manusia; kedua, pembaharuan nilai adat agar selaras dengan prinsip persamaan kedudukan dalam hukum (equality before the law) termasuk nilai-nilai adat yang bias gender; dan ketiga, pembaharuan dan pembenahan administrasi dan manajemen peradilan adat agar dapat lebih akuntabel.

Kondisi peradilan adat yang masih memerlukan pembenahan ini juga sejalan dengan Sinclair Dinnen yang memahami bahwa posisi peradilan adat dalam sistem hukum formal kerap dipertanyakan, bukan hanya terkait dengan pola hubungannya bila keduanya akan diterapkan, akan tetapi juga mencakup sejumlah keraguan berkaitan dengan keberadaan institusi peradilan adat ini antara lain: ${ }^{28}$

(a) Fakta yang menyatakan bahwa kebanyakan peradilan adat dipegang oleh mereka yang sudah tua, dimana kerangka berfikir dari mereka kerap kali tidak melihat kepada perkembangan kondisi yang ada pada masyarakat khususnya generasi muda. Hal ini mempengaruhi putusan yang mereka buat seperti bahwa putusannya mendiskriminasi perempuan dan anak-anak (khususnya dalam masyarakat patrilineal);

(b) Dugaan bahwa dalam peradilan adat pun budaya nepotisme dan korupsi rentan terjadi;

(c) Kekuatan memaksa dari putusan peradilan adat kerap kali diragukan;

(d) Prinsip dan tujuan pemidanaan dari peradilan adat yang berbeda dengan sistem formal yang ada sehingga dampak dari putusan yang dihasilkan pun akan sangat berbeda (dalam hal ini penulis tidak melihat apakah dampak yang dimaksud merupakan dampak positif atau pun negatif);

(e) Bahwa institusi peradilan adat hanya akan effektif dan mengikat dalam masyarakat tradisional yang homogen akan tetapi akan sangat berbeda jika diterapkan dalam lingkup urban-area;

28 Eva Achjani Zulfa, Op.Cit. 
Terkait dengan hal-hal tersebut, maka Sinclair menawarkan model collaborative approach atau hybrid justice system antara peradilan adat dan sistem hukum formal. Namun demikian dalam implementasinya juga harus melihat kepada: ${ }^{29}$

(a) Bahwa perlakuan diskriminatif tidak lagi diterapkan;

(b) Bahwa hukuman yang dijatuhkan harus melihat kepada perkembangan pemidanaan yang mengacu pada penghormatan hak asasi manusia;

(c) Harus pula dipertimbangkan apakah mekanisme ini dapat berlaku bagi pelaku tindak pidana yang serius seperti perkosaan atau pembunuhan; ${ }^{30}$

(d) Adanya jaminan kepastian hukum yang dijamin oleh undang-undang atas setiap putusan yang dibuat melalui jalur informal ini.

Untuk itulah maka harmonisasi nilai adat agar selaras dengan hak asasi manusia, prinsip persamaan kedudukan dalam hukum (equality before the law) dan pemikiran kekinian serta pembenahan administrasi dan manajemen peradilan adat agar dapat lebih akuntabel menjadi sebuah keniscayaan.

\section{a. Harmonisasi Nilai Adat Dengan HAM}

Sebagaimana bahasa, pengadilan adat berkembang bukan karena peran negara. Hukum dan pengadilan adat berkembang dari waktu ke waktu melalui interaksi spontan dari banyak individu dalam masyarakat. ${ }^{31}$ Menurut Baudouin Dupret, kekuatan tersebut sesungguhnya jauh lebih mengikat dibandingkan tekanan yang bisa diberikan oleh hukum negara sebagaimana yang dikatakan: There are many societies who lack any centralised institution enforcing the law, but there is no society which is deprived from these rules which "are felt and regarded as the obligations of one person and the rightful claims ofanother..$^{32}$ Maka wajarjika persepsi masyarakat terhadap keputusan-keputusan pengadilan adat dianggap dapat membawa keadilan sekaligus kepastian terhadap penyelesaian sengketa. Sebagai sebuah lembaga yang paling dekat dengan kesatuan terkecil dari Indonesia, penyelesaian konflik-konflik domestik adalah kekuatan utama pengadilan adat.

Meski demikian, harus diakui pula bahwa masih terdapat nilai-nilai dalam hukum adat yang masih bias gender. Di beberapa komunitas adat masih pula terlihat nilai dan sanksi yang menempatkan perempuan tidak setara hakhaknya dengan laki-laki (bias gender). Sebagai contoh, dalam pelaksanaan pembagian warisan yang terjadi di NTB acapkali ditemukan adanya pelanggaran terhadap hak perempuan untuk memperoleh bagian warisan, hal ini bukan semata-mata karena faktor hukum adat yang tidak mengakomodir hak perempuan, melainkan juga karena perlakuan ahli waris laki-laki yang

29 Ibid.

30 Penulis memandang bahwa pelaku kasus-kasus perkosaan dan pembunuhan tetap ditangani oleh penegak hukum formal, tetapi memberikan peran kepada peradilan adat untuk dapat menangani kasus ini dalam rangka mendamaikan kedua keluarga para pihak agar persoalan yang terjadi tidak makin meluas. Fungsi perdamaian ini sangat penting dan merupakan tujuan utama peradilan adat.

31 Bruce L Benson, "Customary Law with Private Means of Resolving Disputes and Dispensing Justice: A Description of a Modern System of Law and Order without State Coercion," The Journal of Libertarian Studies Vol. IX, No. 2 (1990): 27.

32 Dupret, Baudouin, "Legal Pluralism, Plurality of Laws, and Legal Practices: Theories, Critiques, and Praxiological Re-specification," European Journal of Legal Studies: Issue 1. (tanpa tahun): 2. 
kurang memperhatikan hak Perempuan, baik pada masyarakat Suku Samawa (Sumbawa), Mbojo (Bima) maupun Sasak. ${ }^{33}$

Praktek adat yang bias gender ini juga terjadi dalam pelaksanaan musyawarah adat. Kaum laki-laki selalu berperan sebagai pemimpin, sedangkan kaum perempuan hanya sebagai peserta. Kaum perempuan tidak berhak sebagai pemimpin dalam memimpin rapat maupun jabatan struktural dan fungsional dalam masyarakat. Besarnya peran kaum laki-laki sebagi kepala rumah tangga membawa dampak terhadap lebih besarnya perolehan hak laki-laki dalam pewarisan dibandingkan dengan kaum perempuan. $^{34}$

Kondisi yang masih memerlukan penyelarasan dan pembaharuan ini direspons oleh beberapa komunitas adat di beberapa daerah sehingga kemudian telah ada pula upayaupaya untuk menyelaraskan nilai-nilai adat agar selaras dengan HAM. Di Aceh misalnya, karena dianggap bertentangan dengan hak azasi manusia (HAM), hukum Islam, dan hukum Nasional serta merendahkan harga diri manusia maka telah ditentukan beberapa sanksi atau hukuman yang tidak lagi berlaku dan dituangkan melalui penyusunan sebuah pedoman peradilan adat (guidelines). Sanksi dan hukuman tersebut diantaranya adalah: ${ }^{35}$ dimandikan dengan air kotor, ditenggelamkan ke sungai, dikeroyok/ dianiaya, dan dipukuli. Sedangkan sanksi atau hukuman yang masih berlaku dalam hukum adat aceh adalah: nasihat, peringatan, minta maaf di depan umum, ganti rugi, diusir dari gampong, pencabutan gelar adat, dikucilkan dalam pergaulan, dan diboikot. ${ }^{36}$

Dengan adanya UU Bantuan Hukum yang menganut asas keadilan dan equality before the law ini maka langkah yang sama dalam rangka penyelarasan nilai dan sanksi adat dengan HAM ini bisa dilaksanakan juga oleh daerah-daerah lainnya.

\section{b. Pembaharuan Dan Pembenahan Ad- ministrasi Dan Manajemen Peradilan Adat}

Dengan masih mengacu pada gagasan Sinclair yang menawarkan model collaborative approach atau hybrid justice system yang masih memberikan catatan agar mekanisme penyelesaian perkara melalui peradilan masih memerlukan adanya jaminan kepastian hukum yang dijamin oleh undang-undang atas setiap putusan yang dibuat melalui jalur informal ini, maka perlu juga pembenahan dan pembaharuan administrasi dan manajemen peradilan adat agar mekanisme koordinasi dengan lembaga formal dalam rangka memberikan jaminan kepastian hukum ini dapat berjalan lebih lancar.

Pembaharuan administrasi peradilan perlu dilakukan karena jika tetap pada kondisi tradisional maka potensi penyimpangan seperti yang terjadi di peradilan formal akan terulang terjadi pada peradilan informal. Salah satu faktor yang menjadi penyebab lemahnya upaya reformasi peradilan di peradilan formal adalah

\footnotetext{
33 BPHN, Hukum Adat Yang Melanggar Hak Asasi Perempuan Pada Masyarakat Adat Di Nusa Tenggara Barat (NTB) Dan Nusa Tenggara Timur (NTT) (Jakarta: BPHN 2006), hlm. 51.

34 Ibid., hlm. 44.

35 MAA, "Pedoman Peradilan Adat Di Aceh: Untuk Peradilan Adat Yang Adil Dan Akuntabel, Proyek Bappenas-UNDP, hlm. 27, i http://ind.adatjustice.org/wp-content/ uploads/ publikasi/ Buku\% 20Pedoman\% 20Peradilan. Pdf.

36 Ibid.
} 
kurang efektifnya court management peradilan ${ }^{37}$ atau administrasi peradilan.

Pembenahan administrasi peradilan adat dapat digunakan sebagai sarana atau metode untuk menata-ulang administrasi peradilan yang agar lebih efektif, efisien, transparan, aksesibel serta serta bertanggungjawab dengan tujuan untuk mereduksi serta preventif terhadap berbagai kemungkinan terjadinya praktikpraktik judicial corruption. Namun selain itu pembenahan administrasi peradilan adat juga dapat dijadikan sebagai upaya untuk memberi pijakan bagi munculnya hakim-hakim adat yang memiliki dedikasi, integritas, serta prestasi yang baik sehingga mampu melahirkan putusanputusan yang jujur, adil, tidak memihak dan berkualitas. $^{38}$

Tidak kalah pentingnya dalam proses peradilan perlu ditetapkan adanya time sheet maupun time frame yang jelas, disertai dengan mekanisme reward and punishment yang jelas dan tegas sehingga jalannya proses peradilan dari awal hingga akhir menjadi transparan dan terukur. Hal tersebut sekaligus sebagai bentuk komitmen peradilan adat terhadap masyarakat, terutama pencari keadilan, terkait implementasi asas peradilan sederhana, cepat dan biaya ringan.

Beberapa hal teknis yang perlu dilakukan peradilan adat dalam rangka membenahi administrasi dan manajemennya adalah:

a. Pendokumentasian putusan peradilan adat; b. Pendokumentasian nilai-nilai adat sekaligus menyelaraskan dengan nilai-nilai HAM dan keadilan universal;

c. Regenerasi pemangku peradilan adat;

d. Pendidikan dan pelatihan masyarakat adat yang ditugaskan membantu pelaksanaan peradilan adat.

Semakin kuatnya peradilan adat akan semakin memudahkan mekanisme koordinasi antara peradilan adat dengan aparat penegak hukum formal seperti Kepolisian, Kejaksaan dan Pengadilan Negeri. Hal ini dapat bergayung sambut dengan kebijakan yang dikeluarkan lembagapenegakhukumformal.Sebagaicontoh, Polda Sulawesi tengah juga saat ini tengah mengembangkan program Bantuan Keamanan Desa (BANKAMDES) yang pada level tertentu sejalan dengan semangat untuk penguatan peradilan informal. Sebab, BANKAMDES akan diberikan kewenangan kepolisian terbatas, dimana salah satu tugas pokoknya adalah "melaksanakan restorative justice: dengan menyelesaikan konflik, tipiring dan sengketa lainnya sesuai dengan batas kewenangannya". Hal ini sejalan juga dengan Panduan Perpolisian Masyarakat (POLMAS) Dalam Penyelesaian Perkara Ringan/ Pertikaian Antar Warga yang dikeluarkan oleh MABES POLRI dan juga telah diterapkan dengan baik di wilayah Kalimantan Tengah. ${ }^{39}$

Pemerintah Daerah juga memiliki peran besar bagi upaya pembenahan administrasi dan

Bandingkan dengan Henry P. Panggabean, Fungsi Mahkamah Agung dalam Praktik Sehari-hari: Upaya Penanggulangan Tunggakan Perkara dan Pemberdayaan Fungsi Pengawasan Mahkamah Agung (Jakarta: Pustaka Sinar Harapan, 2001), hlm. v.

38 Bandingkan dengan Ahmad Mujahidin, Peradilan Satu Atap di Indonesia (Bandung: Refika Aditama, 2007), hlm. 209.

39 Data diperoleh dari assessment penulis dalam kegiatan Strengthening Access to Justice di Sulawesi Tengah dan Kalimantan Tengah sepanjang 2012-2013). 
koordinasi dengan institusi formal. Di Kalimantan Tengah misalnya, terdapat Peraturan Daerah No. 16 Tahun 2008 tentang Kelembagaan Adat Dayak di Kalimantan Tengah sebagaimana diubah dengan Peraturan Daerah Provinsi Kalimantan Tengah No.1 Tahun 2010. Selain itu ada juga Peraturan Gubernur No.13 Tahun 2009 tentang Tanah Adat dan Hak-hak Adat Di Atas Tanah sebagaimana diubah dengan Peraturan Gubernur Kalimantan Tengah No.4 Tahun 2012. Dengan adanya regulasi lokal ini maka akan memudahkan koordinasi antara peradilan adat dengan lembaga penegak hukum formal. Beberapa peradilan adat di Kalimantan Tengah bahkan sudah mulai untuk mendokumentasikan putusan-putusan peradilan adat, membuat surat keterangan dengan dilengkapi stempel peradilan adat, dan bahkan merintis adanya berita acara dalam proses peradilan adat. ${ }^{40}$

Upaya pembenahan administrasi dan manajemen peradilan adat ini sekaligus juga bisa menjadi langkah antisipatif lahirnya Undang-undang tentang Pengakuan dan Perlindungan Hak-hak Masyarakat Hukum Adat yang RUU-nya sedang dibahas di DPR. Dalam RUU ini terdapat beberapa pasal yang mengatur mengenai peradilan adat dan kewenangannya. Kemudian, dengan diakuinya mekanisme informal oleh penegak hukum formal maka jalan bagi peradilan adat untuk mendapatkan pengakuan atas putusanputusan yang dibuat juga semakin terbuka.

\section{E. Penutup}

\section{Kesimpulan}

Konsep yang dibangun oleh UU Bantuan Hukum merujuk pada kenyataan bahwa di luar peradilan negara juga terdapat peradilan non formal yang terpasang dan bekerja berdasarkan aturan-aturan tingkah laku dalam menyelesaikan sengketa berdasarkan hukum adat yang hidup dalam masyarakat. Peradilan dipandang sebagai komponen sistem kemasyarakat yang kompleks dan tidak sebagai sumber tunggal dalam distribusi keadilan, seperti dalam pemikiran hukum legalistis-positivistik. Distribusi keadilan tidak hanya dikaitkan dengan upaya pemerataan kesempatan memperoleh keadilan melalui pembentukan peradilan formal dan perangkatperangkatnya, tetapi juga dengan pasangan yang tepat antara forum dan sengketa, dan dengan postulat-postulat penataan sosial berdasarkan hukumadat.Dengan demikiandapat disimpulkan bahwa bantuan hukum yang diberikan kepada penerima bantuan hukum yang menyelesaikan perkaranya melalui peradilan adat dapat masuk dalam kategori bantuan hukum nonlitigasi yang diatur dalam pasal 4 UU No.16 Tahun 2011 tentang Bantuan Hukum.

Dengan adanya UU Bantuan Hukum yang menganut asas; keadilan, persamaan kedudukan di dalam hukum, keterbukaan, efisiensi, efektivitas, dan akuntabilitas, maka akan mendorong peradilan adat untuk melakukan beberapa pembenahan sebagai berikut: Pertama, harmonisasi nilai adat agar selaras dengan asas keadilan termasuk harmonisasi nilai adat agar tidak bertentangan dengan nilai keadilan universal seperti hak asasi manusia; kedua, pembaharuan nilai adat agar selaras dengan prinsip persamaan kedudukan dalam hukum (equality before the law) termasuk nilai-nilai adat yang bias gender; dan ketiga,

40 Data diperoleh dari wawancara penulis dengan Sabran Ahmad, Ketua Dewan Adat Dayak Provinsi Kalimantan Tengah dalam kegiatan assessment Strengthening Access to Justice di Kalimantan Tengah pada 19-21 Maret 2013). 
pembaharuan dan pembenahan administrasi dan manajemen peradilan adat agar dapat lebih akuntabel. Penyelarasan dan pembaharuan nilai-nilai adat yang belum selaras dengan prinsip HAM dan bersifat bias gender ini telah mulai dilakukan oleh beberapa komunitas adat di beberapa daerah seperti di Aceh dan Sulawesi Tengah dengan penyusunan sebuah pedoman peradilan adat (guidelines), yang salah satunya berisi prinsip bahwa hukuman atau sanksi yang merendahkan harga diri manusia tidak lagi berlaku. Selanjutnya, dengan mengacu pada model collaborative approach atau hybrid justice sistem agar mekanisme penyelesaian perkara melalui peradilan memerlukan adanya jaminan kepastian hukum atas setiap putusan yang dibuat melalui jalur informal ini, maka hal ini akan mendorong pembenahan dan pembaharuan administrasi dan manajemen peradilan adat seperti pendokumentasian putusan dengan standar yang jelas agar mekanisme koordinasi dengan lembaga formal dalam rangka memberikan jaminan kepastian hukum ini dapat berjalan lebih lancar.

\section{Saran}

Dari uraian di atas dapat disarankan beberapa hal berikut: Pertama, pemerintah perlu mendorong agar organisasi bantuan hukum $(\mathrm{OBH})$ memberikan prioritas bantuan hukum terhadap kasus-kasus yang diselesaikan melalui peradilan informal, khususnya peradilan adat agar tidak terjadi penumpukan perkara di peradilan formal. Kedua, pemerintah perlu mensosialisasikan bahwa perkara yang sudah ditangani oleh peradilan adat tidak lagi ditangani oleh aparat penegak hukum formal, kecuali perkara pembunuhan atau yang mengakibatkan kematian. Ketiga, pemerintah dapat membantu memberikan dukungan anggaran dan pendampingan kepada masyarakat adat dalam rangka membenahi sistem peradilan adat. Keempat, Organisasi Bantuan Hukum perlu menjalin koordinasi dan membangun hubungan lebih intens dengan lembaga peradilan adat, serta lebih memahami mekanisme peradilan dan perdamaian yang terdapat di dalamnya.

\section{DAFTAR PUSTAKA}

\section{Buku}

BPHN, Hukum Adat Yang Melanggar Hak Asasi Perempuan Pada Masyarakat Adat Di Nusa Tenggara Barat (NTB) Dan Nusa Tenggara Timur (NTT) (Jakarta: BPHN 2006).

Basyaib, et.al., Korupsi dalam Sistem Hukum, (Jakarta: Partnership for Governance Reforfm in Indonesia, 2002)

Hadikusuma, Hilman, Pengantar Antropology Hukum (Bandung: Citra Aditya Bakti, 1992).

Ihromi, T.O. (ed.), Antropology dan Hukum (Jakarta: Yayasan Obor Indonesia, 1984),, hlm. 17.

Ihromi, T.O. (ed.), Antropologi Hukum, Sebuah Bunga Rampai (Jakarta: Yayasan Obor Indonesia, 1993).

Koesno, Muhammad, Musyawarah dalam Miriam Budiardjo (Ed.) Masalah Kenegaraan (Jakarta: tanpa penerbit, 1971).

Lev, Daniel S., Hukum dan Politik di Indonesia (Jakarta: LP3ES, 1990).

Madjid, Nurchalish, Islam Agama Kemanusiaan: Membangun Tradisi dan Visi Baru Islam Indonesia (Jakarta: Paramadina, 1995).

Mujahidin, Ahmad, Peradilan Satu Atap di Indonesia (Bandung: Refika Aditama, 2007).

Ohorela, H.M.G. dan H. Aminuddin Salle, Penyelesaian Sengketa Melalui Arbitrase pada Masyarakat di Pedesaan di Sulawesi Selatan, dalam Felix 0. Soebagjo dan Erman Rajagukguk (ed.), Arbitrase di Indonesia (Jakarta: Ghalia Indonesia, 1995).

Panggabean, Henry P., Fungsi Mahkamah Agung dalam Praktik Sehari-hari: Upaya Penanggulangan Tunggakan Perkara dan Pemberdayaan Fungsi Pengawasan Mahkamah Agung (Jakarta: Pustaka Sinar Harapan, 2001).

Rahmadi, Takdir dan Achmad Romsan, Teknik Mediasi Tradisional Dalam Masyarakat Adat Minangkabau, Sumatera Barat dan Masayarakat Adat di Dataran Tinggi, Sumatera Selatan 
(Jakarta: Indonesia Center For Environmental Law (ICEL), The Ford Foundation 1997-1998).

SAJI, Pedoman Peradilan Adat Di Sulawesi Tengah, (Palu: SAJI Project, 2013).

Shihab, M. Quraish, Wawasan Al-Qur'an (Bandung: Mizan, 1996).

Sulistyono, Adi, Mengembangkan Paradigma NonLigitasi di Indonesia (Surakarta: Sebelas Maret University Press, 2006).

Soekanto, Soerjono dan Sri Mamudji, Penelitian Hukum Normatif: Suatu Tinjauan Singkat (Jakarta: CV. Rajawali, 1990).

Soekanto, Soerjono dan Sri Mamudji, Penelitian Hukum Normatif: Suatu Tinjauan Singkat, edisi 1, cet.v, (Jakarta: PT Raja Grafindo Persada, 2001).

Soekanto, Soerjono dan Sri Mamudji, Peranan dan Penggunaan Perpustakaan di Dalam Penelitian Hukum, (Jakarta: Pusat Dokumentasi Hukum Fakultas Hukum Universitas Indonesia, 1979) .

The Asia Foundation, Survey Report on Citizens' Perceptions of The Indonesian Justice Sector (Preliminary Findings and Recommendations). The Asia Foundation, 2001.

Ubbe, Ahmad, Perbandingan Antara Jumlah Hakim dengan Perkara, Penduduk dalam Pemerataan Memperoleh Keadilan, Majalah Hukum Nasional. No 2/1989 (Jakarta: BPHN, 1989).

Wibowo, Basuki Rekso, Pembenahan Administrasi Peradilan (Jakarta: BPHN, 2012).

Zakiya, Wasingatu dkk, Panduan Eksaminasi Publik (Jakarta: Indonesia Corruption Watch (ICW), 2003).

\section{Makalah / Artikel / Prosiding / Hasil Penelitian}

BPHN, Laporan Pemantauan dan Inventarisasi Perkembangan Hukum Adat (Jakarta: BPHN, 2011).

Hasan, Ahmadi, Penyelesaian Sengketa Hukum Berdasarkan Adat Badamai Pada Masyarakat Banjar dalam Kerangka Sistem Hukum Nasional, Disertasi pada Program Doktor Ilmu Hukum Pasasarjana Fakultas Hukum Universitas Islam Indonesia, Yogyakarta, Tahun 2007.
Hasan, Ahmadi, Penyelesaian Sengketa Melalui Upaya (Non Ligitasi) Menurut Peraturan Perundang-Undangan, Jurnal AL-BANJARI Vol. 5, No. 9, Januari - Juni 2007.

Ubbe, Ahmad, Peradilan Adat Dan Keadilan Restoratif, makalah disampaikan pada Workshop Penyempurnaan dan Strategi Impelementasi Pedoman Peradilan Adat Sulawesi Tengah, Palu, 12-13 April 2013.

Zulfa, Eva Achjani, Keadilan Restoratif Dan Revitalisasi Lembaga Adat Di Indonesia, Dalam Jurnal Kriminologi Indonesia Vol. 6 No.ll Agustus 2010.

\section{Internet}

http://ind.adatjustice.org/wp-content/uploads/ publikasi/Buku\%20Pedoman\%20Peradilan.pdf

http://news.detik.com/read/2012/02/06/190613/ 1835694/10/tunggakan-8-ribu-perkara-tiaptahun-jadi-tantangan-ketua-ma-baru?nd992203 605 pada 1 Maret 2013.

\section{Peraturan}

Undang-Undang Nomor 16 Tahun 2011 tentang Bantuan Hukum.

Undang-Undang Nomor 48 Tahun 2009 tentang Kekuasaan Kehakiman.

Undang-Undang Nomor 30 Tahun 1999 tentang Arbitrase dan Alternatif Penyelesaian Sengketa.

Peraturan Daerah Provinsi Kalimantan Tengah No.1 Tahun 2010 tentang Perubahan Atas Peraturan Daerah No. 16 Tahun 2008 tentang Kelembagaan Adat Dayak di Kalimantan Tengah.

Peraturan Daerah No. 16 Tahun 2008 tentang Kelembagaan Adat Dayak di Kalimantan Tengah.

Peraturan Gubernur Kalimantan Tengah No.4 Tahun 2012 tentang Perubahan Atas Peraturan Gubernur No.13 Tahun 2009 tentang Tanah Adat dan Hak-hak Adat Di Atas Tanah.

Peraturan Gubernur No.13 Tahun 2009 tentang Tanah Adat dan Hak-hak Adat Di Atas Tanah. 